\title{
Derrida, Heaney and the Translation of Virgil's Aeneid, Book VI
}

\section{Ian Hickey}

\section{(2) OpenEdition \\ 12 Journals}

\section{Electronic version}

URL: https://journals.openedition.org/etudesirlandaises/10207

DOI: $10.4000 /$ etudesirlandaises. 10207

ISSN: 2259-8863

\section{Publisher}

Presses universitaires de Caen

\section{Printed version}

Date of publication: 31 December 2020

Number of pages: 101-117

ISBN: 978-2-84133-996-9

ISSN: 0183-973X

\section{Electronic reference}

Ian Hickey, "Derrida, Heaney and the Translation of Virgil's Aeneid, Book VI", Études irlandaises [Online], 45-2 | 2020, Online since 31 December 2020, connection on 15 November 2022. URL: http:// journals.openedition.org/etudesirlandaises/10207 ; DOI: https://doi.org/10.4000/etudesirlandaises. 10207

\section{cc) (이}

Creative Commons - Attribution-NonCommercial-ShareAlike 4.0 International - CC BY-NC-SA 4.0

https://creativecommons.org/licenses/by-nc-sa/4.0/ 


\title{
Derrida, Heaney \\ and the Translation \\ of Virgil's Aeneid, Book VI
}

\begin{abstract}
This article focuses on Seamus Heaney's posthumously published translation of Virgil's Aeneid, Book VI. It does so through the lens of what the post-structuralist thinker Jacques Derrida terms hauntology. In this sense the repetition and return of the past is discussed in relation to the translation in a political and social sense, but also in the context of how Heaney's earlier works often haunt the later works in terms of imagery, thematic output, and word choice. The article examines how the poet pluralises notions of identity through this translation and how this text is one that is haunted by the past in both a historical and literary sense.
\end{abstract}

Keywords: Heaney, Derrida, Virgil, hauntology, Aeneid.

Résumé: Cet article s'intéresse à la traduction par Seamus Heaney du livre VI de l'Énéide de Virgile, publiée de manière posthume. Le prisme adopté est celui de l'hantologie de Jacques Derrida. La répétition et le retour du passé sont analysés en lien avec la traduction au sens politique et social, mais également à travers la manière dont les œuvres antérieures de Heaney hantent souvent les auvres les plus récentes s'agissant des images poétiques, des thématiques et des choix lexicaux. L'article examine la pluralisation des identités par le poète dans cette traduction et analyse la manière dont ce texte est hanté par le passé à la fois historique et littéraire.

Mots clés: Heaney, Derrida, Virgile, hantologie, Énéide.

Seamus Heaney's work is deeply indebted to, and haunted by, literary and cultural inheritances of the past. His poetry fuses his Northern Irish landscape and culture with those of wider, older, and much broader European origins. Heaney's focus on the classical past, as well as other cultures, offers the poet an opportunity to view his present world, the nation, and his own identity through the lens of the past. In his essay "Envies and Identifications: Dante and the Modern Poet", Heaney notes of Eliot's work that when "poets turn to the great masters of the past, they turn to an image of their own creation, one which is likely to be a reflection of their own imaginative needs" ${ }^{1}$ and in Heaney's turn towards Virgil I would argue

1. Seamus Heaney, "Envies and Identifications: Dante and the Modern Poet", Irish University Review, vol. 15, no. 1, 1985, p. 5 . 
that he is doing the same. In much of his poetry Heaney chooses certain instances from other European cultures and texts and moulds them into a work that reflects contemporary society. This article will focus on Heaney's translation of Virgil's Aeneid, Book VI and how he constantly shapes and mingles specific instances from Virgil's masterpiece to suit his own artistic expression.

Mythology, and classical mythology specifically, has had a sustained presence within his poetry from as early on as Death of a Naturalist (1966), in "Personal Helicon", where he makes a reference to Narcissus from Greek mythology. Heaney's indebtedness to the classics is present from very early on; Door into the Dark (1969) sees the presence of Greek myth in the water spirits in "Undine" and the "Midas touch" in "Thatcher" 2; Wintering Out (1972) contains the presence of Leda and the Swan in "Backward Look"; and the line "one eyed and benign" from "Belderg" in North (1975) ${ }^{3}$ calls our attention to Cyclops. While these are only a small collection of examples of the classics in Heaney's earlier work, they show the poet's continuity in mingling his Northern Irish heritage with that of wider, older European poetry. Though there is not the sustained, in-depth melding of classical mythology that we are accustomed to in the middle and later works within the earlier poetry, there is a sense that Heaney is trying to find this path. His first sustained attempt at probing mythology to understand the political turmoil of the nation comes in the form of the bog poems in the 1970s. Here Scandinavian mythologies come to the fore but after the publication of North Heaney turns to Dante's work which itself filters the voice of Virgil's classical writing through it. In Field Work (1979), Heaney moves towards Dante in poems like "Ugolino" and "The Strand at Lough Beg" to once again attempt to understand the violence being enacted upon the people of Northern Ireland by paramilitary organisations. While Dante does have a strong haunting presence throughout much of Heaney's middle poetry, it is the figure that has a seemingly insignificant role up until this point that would ultimately become the major spectral influence on Heaney's work in later years, and this figure is Virgil. Virgil first appears in Field Work as a sort of liminal figure in "The Strand at Lough Beg" with Florence Impens aptly suggesting that "Virgil is only here as a kind of holographic figure with which Heaney could examine his role as a poet, rather than as the author Heaney would explicitly emulate in later years" ". Terming Virgil as a "holographic figure" here, as Impens does, links with Jacques Derrida's notion of the spectre having an absent presence in the present, Virgil is there beneath the surface and is not identifiable as a physical figure in the poem but rather haunts it. Virgil haunts through his influence on Dante's poetry which filters into Heaney's contemporary poetry as well as through Heaney taking Virgil's place at the end of the elegy to his murdered cousin, Colum McCartney.

2. Seamus Heaney, "Thatcher", in Door into the Dark, London, Faber and Faber, 1969, p. 10.

3. Seamus Heaney, "Belderg", in North, London, Faber and Faber, 1975, p. 4.

4. Florence Impens, "Help me please my hedge-school master': Virgilian Presences in the Work of Seamus Heaney”, Irish University Review, vol. 47, no. 2, 2017, p. 253. 
I turn because the sweeping of your feet

Has stopped behind me, to find you on your knees

With blood and roadside muck in your hair and eyes,

Then kneel in front of you in brimming grass

And gather up cold handfuls of the dew

To wash you, cousin. I dab you clean with moss ${ }^{5}$.

At the end of the poem it is Heaney who washes his cousin's face and not Virgil as in The Divine Comedy. The ghosts of McCartney and Dante ultimately return in the later "Station Island" sequence to accuse Heaney for the ways in which he drew the "blinds of the Purgatorio" ${ }^{6}$ to deal with the murder and shows the sense of repetition and return of spectres at work within the poetry but also Heaney's own complex awareness of his use of classical sources. However, despite Virgil not appearing within the poem the spectre of Virgil still resides within it with Jacques Derrida noting of ghosts and spectres in Specters of Marx that "a ghost never dies, it remains always to come and to come back" through the operations of the spectre in the poet's unconscious - that figure which Derrida suggests constantly returns from the past to haunt the present and future. The classical poet is there but not there, he is there because the ghosts of Purgatorio demand that his identity haunt the text despite his name and place within Heaney's version being removed. The haunting nature of Virgil within Heaney's poetry would ultimately grow in significance through the 1980s and especially from the 1990s onwards with the publication of Seeing Things.

In Specters of Marx Derrida suggests that all existence is haunted by spectres of the past. In this text Derrida is pointedly remarking that Marxism can never die because even though it may be gone from common discourse, the fear of Marxism still exists beneath the surface and within the unconscious. Through the operations of the spectre Derrida outlines that the spectre of Marxism always has the ability to return and it is this idea which, when taken outside the context of Marxism and applied to literature, enables a hauntological exploration of texts to take place. Within Specters of Marx Derrida comments that history and the past constantly haunt and influence the present and future through the spectre - "one cannot control its comings and goings because it begins by coming back" 8 One inherits these spectres of the past by being exposed to them and though they may not announce or manifest themselves immediately they reside within the unconscious to reveal themselves at any point in the future:

To bear witness would be to bear witness to what we are insofar as we inherit, and that - here is the circle, here is the chance, or the finitude - we inherit the very thing that allows us to bear witness to it ${ }^{9}$.

5. Seamus Heaney, "The Strand at Lough Beg”, in Field Work, London, Faber and Faber, 1979, p. 10.

6. Seamus Heaney, "Station Island”, in Station Island, London, Faber and Faber, 1984, p. 83.

7. Jacques Derrida, Specters of Marx, Peggy Kamuf (trans.), London, Routledge, 2006, p. 123.

8. Ibid., p. 11.

9. Ibid., p. 68 . 
The return of these spectres hinders ontological certainty as the present and future contain constant traces of the past. The disjointing of time, especially in terms of translation, puts the contemporary in touch with the past. So, when we read Heaney's poetry and find traces of Virgil or Dante's poetry working in a contemporary context we are given to the hauntological as "translations themselves are put 'out of joint"' 10 . The place of Virgil's Aeneid within Heaney's work is indebted to the sense of inheritance and transmission of spectres of which Derrida speaks, "I inherit something that I must also transmit" ${ }^{11}$, and so when Heaney encounters these ghosts through reading they become transmitted through his work. In Stepping Stones, Heaney's book of interviews with Dennis O'Driscoll, he talks of his teacher Father Michael McGlinchey and his influence in opening his young mind to Virgil:

I was lucky too in the teacher I had during my senior years: Father Michael McGlinchey, who loved the language and had a feel for the literary qualities of the texts - especially Virgil. One of our set books was Book Nine of the Aeneid, but I always remember him repeating at different times, "Och, boys, I wish it were Book Six" - which gave me an interest in that book long before I ever read it ${ }^{12}$.

In this sense, the spectre of Virgil resided within the poet's unconscious until the late 1970s when it came to the surface after Heaney being initially exposed to it during his school years. This reinforces the nature of hauntology which Derrida attests to. In his translator's note to the posthumously published Aeneid Book VI Heaney again cites Father McGlinchey as a figure he is indebted to:

This translation of Aeneid VI is neither a "version" nor a crib: it is more like classics homework, the result of a lifelong desire to honour the memory of my Latin teacher at St Columb's College, Father Michael McGlinchey ${ }^{13}$.

The posthumous publication of Heaney's translation of Aeneid, Book VI is also rather uncanny and hauntological as it appeared three years after the poet had passed away. This translation itself was not fully finished at the time of Heaney's unfortunate death though we are told that the published piece

[...] follows the author's latest instructions, and contains no editorial interventions beyond the correction of literals. [...] the author's use of the word "final" may be considered a more precise description of the text than "finished", as well as one in keeping with the Aeneid's own halted composition ${ }^{14}$.

10. Jacques Derrida, Specters of Marx, p. 21.

11. Jacques Derrida, Bernard Stiegler, Echographies of Television: Filmed Interviews, Jennifer Bajorek (trans.), Cambridge, Polity Press, 2002, p. 112.

12. Seamus Heaney, Dennis O'Driscoll, Stepping Stones: Interviews with Seamus Heaney, London, Faber and Faber, 2009, p. 295-296.

13. Virgil, Aeneid Book VI [2016], Seamus Heaney (trans.), London, Faber and Faber, 2017, p. xi.

14. Ibid., p. 53. 
This insight into the work allows for a certain degree of finality to be removed - there is no ending except a living piece of art that remains itself entirely ghostly. Rachel Falconer comments on Heaney's translation that

[...] if we confer on Heaney's translation the prophetic status of the golden bough, we risk divesting the work of its restless, transformative energy. Heaney's dialogue with Virgil was human, unfinished and unfinalizable which makes his Aeneid VI a living work rather than a museum piece ${ }^{15}$.

Heaney's full translation of Book VI mirrors his previous work that includes Virgil. In reading Heaney's translation it is difficult to separate his previous works that are haunted by the classical poet from this discussion. Poems such as "The Golden Bough" (Seeing Things), “Album” (Human Chain), "Route 110” (Human Chain), and "The Riverbank Field" (Human Chain) are all deeply haunted by Virgil's Aeneid and thusly have a hauntological presence within the full translation of Book VI. Similarly, poems such as "Bann Valley Eclogue" (Electric Light) and "Virgil: Eclogue IX" (Electric Light) can also be drawn into the discussion because of their political context - they were written after the ceasefire in Northern Ireland had been agreed and the Good Friday Agreement had been signed. Though these poems are primarily haunted by Virgil's Eclogues they do find a place within Heaney's Aeneid Book VI through their ability to be read in terms of civil war, colonialism and Empire, all of which both Heaney and Virgil experienced during their lives and both their nations experienced also. In what Catherine Heaney and Matthew Hollis see to be a possible fragment of an afterword to the book, Heaney comments that Book VI is the best and worst of books, the best because of its mythopoeic visions and encounters with shades in the underworld and the "worst because of its imperial certitude, its celebration of Rome's manifest destiny and the catalogue of Roman heroes" ${ }^{16}$. While much of Virgil's work stems from the pastoral and deals with issues of civil war and upheaval, in the Eclogues his work developed more politically almost becoming imperial propaganda upon the publication of the Aeneid. Philip Hardie proposes that "the Aeneid plays a major part in the invention of the European myth of Empire" ${ }^{17}$ which is an interesting juxtaposition when compared with Heaney's poetry that questions the results of Empire in its depiction of the violent atrocities of the Troubles. This begs the question as to why Heaney might have been drawn to such writing given that he does not relent in his stance of not conforming to tribal pressures which we see in "The Flight Path" where he talks of being approached by Danny Morrison, a Sinn Féin representative. Heaney’s response is telling of his position on the tribal:

15. Rachel Falconer, "Heaney and Virgil's Underworld Journey", in Seamus Heaney and the Classics: Bann Valley Muses, Stephen Harrison, Fiona Macintosh, Helen Eastman (eds.), Oxford, Oxford University Press, 2019, p. 181.

16. Virgil, Aeneid Book VI, Seamus Heaney (trans.), p. 51.

17. Philip Hardie, The Last Trojan Hero: A Cultural History of Virgil's “Aeneid”, London, I. B. Tauris \& Co. Ltd., 2014, p. 93. 
"When for fuck's sake, are you going to write Something for us?" "If I do write something, Whatever it is, I'll be writing for myself." 18

This translation of Aeneid, Book VI, while it does draw on notions of Empire and Virgilian themes, the very act of translation by Heaney as a Northern Irish poet adds a sense of plurality and universality to the book. When writing of Heaney's translations of Beowulf and The Cure at Troy Eugene O'Brien comments that

Heaney's notion of translation is transformative in that meaning is rendered as a process of interpretation as opposed to a fixed essence. This creative concept of translation allows him to engage with the matter of the past while at the same time taking up a form of critical distance from the past ${ }^{19}$.

In translating, Heaney ultimately delivers a creative output that reads the original text anew and pluralises notions of meaning and understanding surrounding the translated text. Heaney's Aeneid Book VI is deeply haunted by Virgil's original through the progression of Aeneas into the underworld to meet the shade of his father, acquiring the Golden Bough, meeting Charon, and the shades who dwell in the underworld. However, what sets Heaney's translation apart from others is that this full translation is not only haunted by Heaney's poetry which finds a place in the work, but that it is also spectrally indebted to his upbringing in Northern Ireland. Heaney noted of this translation that

[...] that sixth form homunculus must contend with a different supervisor, a writer of verse who has things other than literal accuracy on his mind and in his ear; rhythm and metre and lineation, the voice and its pacing, the need for a diction decorous enough for Virgil but not so antique as to sound out of tune with a more contemporary idiom ${ }^{20}$.

This is a translation that stays close to Virgil's original but offers a new perspective on the old. From the outset we are reminded that this is a translation originating in Heaney's Northern Irish mindscape through the language used and Heaney's word selection:

Now a band of young hotbloods vaults quickly out

On to the shore of Italia, some after flint

For the seedling fire it hides in its veins,

Some crashing through woodland thickets, the haunts

Of wild beasts, pointing amazed at new rivers.

But Aeneas, devoted as ever, has taken the road

Up towards a fort, the high seat of Apollo,

18. Seamus Heaney, "The Flight Path", in The Spirit Level, London, Faber and Faber, 1996, p. 25.

19. Eugene O'Brien, "Seamus Heaney and the Ethics of Translation", Canadian Journal of Irish Studies, vol. 27, no. 2, 2003, p. 23.

20. Virgil, Aeneid Book VI, Seamus Heaney (trans.), p. xiii. 
Then on to a place apart, a vast scaresome cavern, The Sibyl's deep-hidden retreat ${ }^{21}$.

While the scene is uniquely Virgilian we are delivered a contemporary, modern description in "haunts / Of wild beasts" and a reference to a "scaresome cavern". Here we are reminded of Heaney's first poem that dealt with classical mythology, "Personal Helicon", in the use of the word "scaresome". In the fourth stanza of "Personal Helicon" Heaney speaks of echoes from the wells where he grew up:

Others had echoes, gave back your own call

With a clean new music in it. And one

Was scaresome for there, out of ferns and tall

Foxgloves, a rat slapped across my reflection ${ }^{22}$.

It is fitting that the opening lines of Heaney's posthumously published translation would itself echo his poem that first references classical mythology. While there may be wild beasts in the opening of the Aeneid Book VI, in "Personal Helicon" the local beasts take the form of a rat. The connectedness of both sections signals the sense of repetition and return that is intrinsic to Heaney's work. Derrida would suggest that this connectedness is as a result of the spectre and proposes that:

Once ideas or thoughts (Gedanke) are detached from their substratum, one engenders some ghost by giving them a body. Not by returning to the living body from which ideas and thoughts have been torn loose, but by incarnating the latter in another artifactual body, a prosthetic body, a ghost of spirit, one might say a ghost of the ghost if, as Marx sometimes leads one to think, the first spiritualization also, and already, produces some specter ${ }^{23}$.

In terms of Heaney's work, this ghost of a ghost, this other artifactual body, presents itself in Heaney placing a contemporary Irish essence within this Virgilian text. In "The Riverbank Field" he writes that "I will confound the Lethe in the Moyala" ${ }^{24}$ and it is exactly this which Heaney achieves within Human Chain as a whole, but also in the sense of his translation of Aeneid, Book VI. Heaney pluralises notions of identity that exist within Virgil's text. In undertaking a full translation of Book VI he is breathing new life into the text but also, I would argue, probing a working parallel between his world and Virgil's, his desire to meet the shade of his father, and also the ability to realise that while Virgil's text propagated notions of Empire and colonialism, his text opens a dialogue with the Other. In the act of translation Heaney skews preconceived notions of what this text means in a universal sense because he brings with him the spectres of his work, his identity, and

\footnotetext{
21. Ibid., p. 3.

22. Seamus Heaney, "Personal Helicon", in Death of a Naturalist, London, Faber and Faber, 1966, p. 44.

23. Jacques Derrida, Specters of Marx, p. 157-158.

24. Seamus Heaney, “The Riverbank Field”, in Human Chain, London, Faber and Faber, 2010, p. 46.
} 
his culture as a Northern Irish nationalist. In an interview with Lorna Hardwick he spoke of the importance of classical literature noting that "I once said that the classics are like the longitude and latitude of consciousness in the West, they establish the first lines of thought and feelings" 25 and through the classics Heaney is enabled to stake his place in the world, to understand certain feelings, emotions and events that are commonly shared with Aeneas and the classical past.

Commenting on Heaney and the act of translation Silvia Geremia makes the point that

A linguistic and cultural system turns into another, because the language and the thought of the "other" is changed into the language and thought of the "self" to be received in a different cultural context ${ }^{26}$.

Taken in the context of Aeneid, Book VI we are drawn to certain commonalities between the translation, Heaney's poetry, and his cultural heritage as the cultural context of the full translation sways between Virgilian and contemporary times and gives rise to ontological uncertainty, a key feature of hauntology. The notion of descent that revolves around the Aeneid in Aeneas's journey down into the underworld strikes a chord with the notion of digging and probing downwards in Heaney's poetry. We see notions of digging, descent, and earth combined in lines 353-356 of Heaney's translation:

Let assent be forthcoming

As I tell what's been given to tell, let assent be divine

As I unveil things profoundly beyond us,

Mysteries and truth buried under the earth ${ }^{27}$.

It is interesting here that we see the notion of descent revealing new information, but it is also important to note the presence of assent within these lines. In an overall viewing of Heaney's poetic career it first started with the notion of digging downwards to understand his place in the world in "Digging" or to understand the political and sectarian violence of the Troubles in Wintering Out and North, while light and air are intrinsic to the later poetry in poems such as "Fosterling" and "A Kite for Aibhín”. The spectres of Heaney's past poetry return to haunt this translation. The sense of cultural violence and war that pervades much of Aeneid, Book VI is also applicable to Heaney's own Northern Ireland. From lines 20 to 31 we can attribute a commonality between the Northern Irish Troubles, the bog people of Scandinavia, and the Athenians of Virgil's text. Heaney's translation notes that Dedalus flew to the "north, through the cold air" ${ }^{28}$ and acknowledges "seven

25. Lorna Hardwick, Interview with Seamus Heaney, September 2017, on line: www.open.ac.uk/arts/ research/pvcrs/sites/www.open.ac.uk.arts.research.pvcrs/files/files/Heaney_transcript_PDF(1).pdf.

26. Silvia Geremia, “A Contemporary Voice Revisits the Past: Seamus Heaney's Beowulf”, Estudios Irlandeses, no. 2, 2007, p. 59.

27. Virgil, Aeneid Book VI, Seamus Heaney (trans.), p. 16.

28. Ibid., p. 4. 
grown-up sons for sacrifice every year" ${ }^{29}$. What is most interesting about Heaney's translation is the inclusion of "north" in his version while other translations of that scene go as follows:

When Daedalus, to fly the Cretan shore,

His heavy limbs on jointed pinions bore,

(The first who sail'd in air,) 'tis sung by Fame ${ }^{30}$.

Similarly, a translation undertaken by Frederick Ahl goes as follows:

Daedalus pitied a ruler in her great love. He untangled

Ruses and structural mazes and ruled them a route upon unseen

Tracks with a guiding thread. You, Icarus, too would have figured

Large in this masterly work, If his rueful pain had permitted.

Twice he attempted to shape what befell you, in golden relief-work;

Twice, what fell were your father's hands ${ }^{31}$.

In both versions there is no reference to going "north", this is only present in Heaney's version. Both Dedalus and Heaney have depicted images of sacrifice and violence within their given artforms. While Dedalus inscribes his upon stone, Heaney portrays modern society on the page. This connectedness between the mythical Dedalus and Heaney, and of course Heaney and Virgil, allows a sense of universality to emanate from Heaney's work. In his earlier work Heaney sought to understand the violence his nation was witnessing in line with the sacrificial victims of violence of Scandinavia in poems like "The Tollund Man" and "The Grauballe Man" and this pluralisation of cultures and identities is what he is expounding yet again in Aeneid Book VI. Derrida would argue that the sacrifice of seven sons in Virgil's text, the sacrifice of individuals to the bog in the Iron Age, and the victims of violence in contemporary Ireland are all linked through the operations of the spectre with Derrida stating that "a heritage is never natural, one may inherit more than once, in different places and at different times" 32 . Taken in this context I would argue that the inheritance of violence is cultural and repetitious throughout history and that by Heaney stating that Dedalus moves "north" instead of "sail'd in the air" he is drawing our attention towards the ways in which the classical world is intermingled with his own experiences, and the Northern geographical setting of Heaney's poetry also. Heaney's translation offers a new variation on Virgil's classical text, one that cannot be taken out of the context of his own culture and history given that the poet has so often probed the ways in which contemporary scenes can be viewed in a classical manner, or - as Florence Impens suggests - Heaney casts "Ireland as one of the major European cultures, directly derived from a

\footnotetext{
29. Ibid.

30. Virgil, The Aeneid, London, Harper Press, 2013, p. 162-163.

31. Virgil, Aeneid, Frederick Ahl (trans.), Oxford, Oxford University Press, 2007, p. 129.

32. Jacques Derrida, Specters of Marx, p. 211.
} 
classical past" ${ }^{33}$. The manner of the sectarian violence in Northern Ireland finds a sustained spectral presence within Heaney's translation in lines such as "O gods, as my plea for vengeance is just one. Gods! / Retaliate! Strike the Greeks with all due punishment" 34 and in:

Vengeful Tisipone keeps bearing down, a whiplash

Lapped and lithe in her right hand, in her left

A flail of writhing snakes, scourging the guilty,

Summoning her ferocious claque of sisters ${ }^{35}$.

While these lines do recognise the level of the repetition of violence in life and in the underworld, the most recognisable lines in relation to Heaney's past poetry springs from the description of Tityos in the underworld:

Vulture puddles forever with hooked beak

In his liver and entrails teeming with raw pain.

It burrows deep below the breastbone, feeding

And foraging without respite, for the gnawed-at

Gut and gutstrings keep renewing ${ }^{36}$.

This renewability of violence is rather striking when taken in the context of Heaney's work overall. He has constantly probed Greek, Roman and Scandinavian instances of such violence but the poem that seems to be most appropriate in its thematic closeness to these lines is from Heaney's "Ugolino" in Field Work. The hauntological essence of Heaney's translations intensifies as "Ugolino" itself is haunted by Dante's Inferno Cantos xxxii and xxxiii where Virgil guided him on his journey. Heaney wrote "Ugolino" in an attempt to understand the repetition of violence within Northern Ireland and found in the image of Count Ugolino feasting upon the skull of Archbishop Roger in the underworld a correlation between both worlds. Once Ugolino has recounted his reasons for seeking revenge he does not stop this violence but instead renews and carries on with it:

When he had said all this, his eyes rolled

And his teeth, like a dog's teeth clamping round a bone,

Bit into the skull and again took hold ${ }^{37}$.

This repetition of violence carries across and haunts three different cultures here as it occurs in Virgil's time, Dante's time, and now in Heaney's. Silvia Geremia observes that after the publication of Beowulf in 1999 "many scholars observed that Heaney created a completely new literary work in which the story of Beowulf

33. Florence Impens, Classical Presences in Irish Poetry After 1960: The Answering Voice, London, Palgrave Macmillan, 2018, p. 45-46.

34. Virgil, Aeneid Book VI, Seamus Heaney (trans.), p. 29.

35. Ibid., p. 32.

36. Ibid., p. 33.

37. Seamus Heaney, "Ugolino", in Field Work, p. 63. 
is seen, for the first time, through Irish eyes" ${ }^{38}$. Virgil's text had undergone a translation in medieval Ireland into Gaelic, Imtheachta Aeniasa, but the crux of Geremia's argument when applied to Heaney's full translation of Book VI offers a translation through contemporary Irish eyes. While Heaney may not create a wholly new literary work because it is deeply grounded in the thematic output of the original, what he does accomplish here is a viewing of Virgil's work through the prism of Irish culture and his own identity, both literary and personal. The spectres that haunt Heaney's translation allow a new angle in which to interpret and view Virgil's masterpiece as the spectres of both periods blend and clash which "produces an automatism of repetition" 39 . Heaney's translation becomes one that is not totally Virgilian but one that offers a contemporary twist on the original. His work is a melding of his own values and perspectives with those of classical origin. In Stepping Stones, Heaney comments that:

When I say "canon", I’m thinking Homer, Virgil, Dante, Shakespeare... These are nuclear deterrent words almost! But they can be reread in terms of new idioms. Which is to say they are classics, secure because of their human and foundational quality. Another voice will cry out that that's a Eurocentric attitude to things. It certainly is - that's where they come from and where I live and it's part of my equipment for locating myself in time and consciousness. You don't have to abandon values which you have created yourself in order to be open in the world to other values ${ }^{40}$.

Heaney's recasting of the classics to form new representations is intrinsic to his work as a poet and as a translator in general. He maintains, and rightly so, that the classics are secure enough in their place in the literary world and therefore by offering a translation that slightly alters them to suit one's own needs is agreeable. Also, I would argue, it is the poet's artistic licence that enables this - it is their artistic expression and therefore they are free to do what they wish. So, while this text has an obvious fingerprint of Heaney's on it, the wider hauntings and spectres that dwell within it come to the fore. Where Virgil's original is an outpouring of Empirical strength and colonial mastery which in an Irish context may be read in terms of British colonial exploits in Ireland, Heaney's version offers a postcolonial angle that enables a dual interpretation of the text, and therefore breaths new life into readings of the work. Derrida suggests of hauntology and the spectre that:

The subject that haunts is not identifiable, one cannot see, localize, fix any form, one cannot decide between hallucination and perception, there are only displacements; one feels oneself looked at by what one cannot see ${ }^{41}$.

And in this sense Heaney's translation when taken literally is referencing Roman colonialism and the spread of empire but the Irish spectres that lurk beneath the

38. Silvia Geremia, “A Contemporary Voice Revisits the Past...”, p. 58.

39. Jacques Derrida, Specters of Marx, p. 217.

40. Seamus Heaney, Dennis O’Driscoll, Stepping Stones..., p. 456.

41. Jacques Derrida, Specters of Marx, p. 169-170. 
surface of the text enable for the following lines to be taken within the context of British imperialism in Ireland:

Once he inaugurates the power of Rome,

She in her glory will push an empire's bounds

To the ends of earth and harbour aspirations

High as heaven $[\ldots]^{42}$.

Heaney has often explored the contested nature of identity within Northern Ireland in his poetry and the impact that colonialism has had in causing this. In poems like "Oceans Love to Ireland" and "Bog Oak" he references two key figures in the implementation of British colonialism in Ireland; Walter Raleigh and Edmund Spenser. Michael Parker proposes that "Oceans Love to Ireland" is a poem that sets about demystifying the colonial cloud that blocks the truth behind imperialism. He presents his case that the poem

[...] debunks the myth of English "civility" in its treatment of what is euphemistically termed Anglo-Irish "relations" between the late sixteenth and early eighteenth centuries ${ }^{43}$.

This poem offers a realistic interpretation of an early phase of colonialism in Ireland but that does not mean Heaney is anti-British, rather that he is acknowledging historical facts in terms of the violence of the colonising process even if it is ideologically attenuated by poetry and literature such as that of Raleigh. Heaney has commented on both Spenser and Raleigh that:

I read them first as textbook poetry; they were part of my learning process: finding where I was in the world of culture... But you can live with so many truths at once. You can take pleasure in their verse yet understand that they were racist theorists, contributors to a nascent English imperialism. Edmund Spenser writes a treatise for the elimination of the native Irish: either they can be made English or they can be done away with. Incidentally, when I was teaching in Harvard, I'd say, "This Spenserian attitude towards the native population worked better in New England" ${ }^{44}$.

In this sense, this is exactly what Heaney is achieving in his translation of Aeneid, Book VI. The fact that Virgil's original is staunchly Empirical does not seem to bother Heaney, he is combing the literary aspects of the text that have a certain element of meaning for him and is acutely aware of Virgil's meanings, as he acknowledged in saying that "it is the best of books and the worst of books" 45 . While the colonial aspects of the texts are present, "Love of country will prevail and the overwhelming/ Desire for fame" ${ }^{46}$, when Anchises is describing those who

42. Virgil, Aeneid Book VI, Seamus Heaney (trans.), p. 42.

43. Michael Parker, Seamus Heaney: The Making of the Poet, Iowa, University of Iowa Press, 1994, p. 142.

44. Seamus Heaney, Dennis O’Driscoll, Stepping Stones..., p. 455.

45. Virgil, Aeneid Book VI, Seamus Heaney (trans.), p. 51.

46. Ibid., p. 44. 
dwell in Elysium he comes across Tullus. This is in reference to Tullus Hostilius who was the third King of Rome, after Romulus and Numa Pompilius. His rulership of Rome from 673-642 BC was defined by war. Henry George Liddell has written of Tullus that:

His reign of two-and-thirty years was as bloody and warlike as that of Numa had been calm and peaceful. [...] The chief war of Tullus was against the Albans. It broke out thus. The lands of Rome and Alba marched together, that is, they bordered one upon the other, and the borderers of other nations had frequent quarrels and plundered one another. King Tullus took up the cause of his people, and demanded restitution of the booth taken by the Albans ${ }^{47}$.

This ultimately caused war between both Rome and Alba. Once defeated, Rome took control of the lands of Alba and incorporated both societies together in an expansion of Roman territory. The inclusion of Tullus's Empirical tendencies within Virgil's Aeneid acts as a celebration of the past glories of the Empire whereas in Heaney's translation there is an element of critique at play:

To be succeeded next by Tullus, who will wreck

His country's peace, turn an easygoing people

Militant and drill an army long out of the field

For victory ${ }^{48}$.

Heaney's translation is rather critical here of the imperial nature of Virgil's text in the description of Tullus as a wrecker of peace. In other translations the lines go as follows:

An active prince, and prone to martial deeds.

He shall his troops for fighting fields prepare,

Disus'd to toils, and triumphs of the war.

By dint of sword his crown he shall increase,

And scour his armor from the rust of peace ${ }^{49}$.

Both sections of the same passage of Virgil's text are totally different in their thematic output. While both stay true to the course of the Aeneid, Heaney subverts the intended meaning of the description of Tullus in order to devalue the glorification of Empire. Heaney's translation further engenders a contemporary Irish sway to it here, especially in the use of modern language usage such as in "easygoing people". The poet's cultural inheritance and upbringing as a member of the nationalist community in Northern Ireland obviously has deep connotations here in his stance against colonialism and sectarian violence in general. There are multiple hauntologies at work within this translation as the spectres of Roman colonialism,

47. Henry George Liddell, A History of Rome, From the Earliest Times to the Establishment of the Empire, London, John Murray Publishers, 1855, p. 37.

48. Virgil, Aeneid Book VI, Seamus Heaney (trans.), p. 44.

49. Virgil, The Aeneid, London, Harper Press, 2013, p. 195. 
British colonialism, contemporary Northern Ireland, and Heaney's own personal and literary heritage combine to haunt and influence this working piece of literature. In terms of these absent presences within the translation Derrida would suggest that

It is a proper characteristic of the spectre, if there is any, that no one can be sure if by returning it testifies to a living past or to a living future, for the revenant may already mark the promised return of the spectre of living being. Once again, untimeliness and disadjustment of the contemporary ${ }^{50}$.

The translation again attests to the hauntological as ontological certainty is blown open as we encounter ghosts of Roman, British, and Northern Irish origins in a text that derives from Roman times.

This return of spectres of the past is nowhere more visible in their disadjustment of the contemporary within the translation than when we probe the extent to which it is haunted by Heaney's previous poetic dealings with Virgil. The most obvious connection is with the Golden Bough which Heaney translated at the start of Seeing Things, after the death of his father. In their introduction to Seamus Heaney and the Classics: Bann Valley Muses Stephen Harrison and Fiona Macintosh argue that the "capacity to unite familial affection with larger literary ambition is a key characteristic of Heaney's Virgilian reception" ${ }^{51}$ and this characteristic still resonates with the full translation of Aeneid, Book VI as we can read it in the context of Heaney's own life and experiences. The Golden Bough section of the Aeneid is deeply poignant in relation to his own dealings with his father's death and the mythical undertakings Aeneas undergoes in an attempt to meet the shade of his father in the underworld was deeply important to Heaney:

But there's one Virgilian journey that has indeed been a constant presence and that is Aeneas's venture into the underworld. The motifs of Book VI have been in my head for years - the golden bough, Charon's barge, the quest to meet the shade of the father ${ }^{52}$.

Both Heaney's 1991 version of “The Golden Bough" and the section translated in his version of Book VI are deeply haunting in a literary sense. There are some minor syntactical changes and alterations of words but for the most part they are relatively the same. In "The Golden Bough" a section of the poem goes as follows:

For already I have foreseen and foresuffered all.

But one thing I pray for especially: since they say it is

here

That the King of the Underworld's gateway is to be

found,

50. Jacques Derrida, Specters of Marx, p. 123.

51. Stephen Harrison, Fiona Macintosh, "Introduction", in Seamus Heaney and the Classics: Bann Valley Muses, Stephen Harrison, Fiona Macintosh, Helen Eastman (eds.), Oxford, Oxford University Press, 2019, p. 7.

52. Seamus Heaney, Dennis O’Driscoll, Stepping Stones..., p. 389. 
Among these shadowy marshes where Acheron comes flooding through,

I pray for one look, one face-to-face meeting with my dear father ${ }^{53}$.

Whereas with the publication of Aeneid Book VI twenty-five years later there are some minor changes:

\section{[...] for I have foreseen \\ And foresuffered all. But one thing I pray for \\ Especially: since here the gate opens, they say, \\ To the King of the Underworld's realms, and here \\ In these shadowy marshes the Acheron floods \\ To the surface, vouchsafe me one look, \\ One face-to-face meeting with my dear father ${ }^{54}$.}

The most obvious change is stylistic as both translations differ in form and structure. Heaney's retention of certain key phrases is significant in the presence of the literary inheritance that surrounds his full translation of Aeneid, Book VI. Phrases such as "I have foreseen / And foresuffered all" and "One face-to face meeting with my dear father" are present within both sections while the line "A man in old age, worn out yet holding out always" ${ }^{55}$ changes to "a man in old age, worn out, not meant for duress" in Aeneid Book $V I^{56}$. These phrases are extremely significant as they show that Heaney's work is not only haunted by spectres of other cultures and traditions, but that it is also haunted by itself in that phrases and imagery repeat themselves in works that follow. The spectral presence of Eliot's poetry also transmits into the phrase "I have foreseen / And foresuffered all" because here we recall T. S. Eliot's The Waste Land in "And I Tiresias have foresuffered all" ${ }^{57}$. The opening of that Eliot poem also finds a deeply applicable trace within Heaney's translation of Virgil's Aeneid, Book VI, and especially the Golden Bough section, through Eliot's lines "mixing/memory and desire" 58 . The long sections from both "The Golden Bough" and Aeneid Book VI, from which I have quoted above, are indebted to this sense of mixing memory and desire through Heaney's wish to meet the shade of his father once more in a wholly imaginative and literary sense. The line "A man in old age, worn out, not meant for duress" 59 draws us to "Album" from Human Chain. In "Album" Heaney recounts his father in later years in section IV of the sequence:

53. Seamus Heaney, “The Golden Bough”, in Seeing Things, London, Faber and Faber, 1991, p. 1-2.

54. Virgil, Aeneid Book VI, Seamus Heaney (trans.), p. 8-9.

55. Seamus Heaney, “The Golden Bough", p. 1.

56. Virgil, Aeneid Book VI, Seamus Heaney (trans.), p. 9.

57. T. S. Eliot, Collected Poems 1909-1962, London, Faber and Faber, 2002, p. 53.

58. Ibid.

59. Virgil, Aeneid Book VI, Seamus Heaney (trans.), p. 9. 
Helping him to the bathroom, my right arm

Taking the webby weight of his underarm ${ }^{60}$.

The absent presence of “Album” in Heaney's translation of Aeneid, Book VI also finds a place in Aeneas's three failed attempts to hug his father Anchises in the underworld, as well as the presence of so many family members in both poems:

Three times he tried to reach arms round that neck.

Three times the form, reached for in vain, escaped

Like a breeze between his hands, a dream on wings ${ }^{61}$.

The haunting connections also multiply because in section IV of "Album" Heaney himself fails to hug his own father after three attempts which mirrors Aeneas's failed attempts to hug Anchises in the underworld. Throughout his poetry, and indeed in this translation of Book VI, Heaney recasts certain instances from Virgil's writing that parallel contemporary society. Indeed, the speaking subject within the translation is Janus faced and polysemic, encompassing past and present at the same time as the spectral voices of Virgil's Aeneid resonate throughout Heaney's modern translation. Derrida comments on the nature of a successful translation:

[...] a translation that does what one expects of it, in short, a version that performs its mission, honors its debt and does its job or its duty while inscribing in the receiving language the most relevant equivalent for an original $[\ldots]^{62}$.

Heaney's translation is a work that pays attention to the different strains of Virgil's original while offering a contemporary twist to it through word choices and the interpenetration of spectres of the past and the present. Since Heaney's imprint is on the translation the spectres that manifest from his identity, culture, and literary heritage are also intertwined within this work.

"Route 110" also holds a deeply hauntological place within Aeneid Book VI as the earlier poem laid much of the groundwork for the later full translation. On the surface his translation of Aeneid, Book VI adheres to the Virgilian dimensions of the original text more than "Route 110" in Human Chain. "Route 110" sees Heaney explicitly and imaginatively mirror Aeneas's journey into the underworld but in a manner that is strictly personal. The classical undertones within "Route 110" merely act as a guide to the poet rather than as a strict blueprint that must be adhered to but again family is to the fore of the sequence. "Route 110" acts as a way of Heaney looking backwards into the past as well as a way of attempting to understand the events of that past whether it is the murders of Louis O'Neill and John Lavery, the death of Michael Mullholland or the purchase of his second hand book of Virgil's Aeneid. Just as that copy would give birth to the mythical undertakings Heaney

60. Seamus Heaney, "Album”, in Human Chain, p. 7.

61. Virgil, Aeneid Book VI, Seamus Heaney (trans.), p. 38.

62. Jacques Derrida, “What Is a 'Relevant' Translation?”, Lawrence Venuti (trans.), Critical Inquiry, vol. 27, no. 2, 2001, p. 177. 
experiences in that sequence, Virgil's Aeneid, Book VI also enables him to add an air of continuity to the translation process of that work. The later full translation cannot help but being read within the context of "Route 110", and indeed all of Heaney's past poetry, as the frame of reference in his Aeneid Book VI is deeply personal. In translating Virgil into his poetry he succeeds in looking back but also forward at the same time with the act of translation itself giving new life and perspectives to the past. Michael Parker discusses this hunger for translation as Heaney:

[...] referring to himself critically then and now, how he has hungered after new experiences and stepping-off points, perhaps in compensation for or as a distraction from an aching lack. Against that must be set his recognition that for any human being seeking individuation - not least a poet and critic - a constant receptivity to "translation" is an absolute necessity ${ }^{63}$.

In seeking individuation Heaney has attained immortality through his poetic works but especially through his final published work Aeneid Book VI. It is fitting that a book that has been so important to Heaney and one that ultimately set him off on his classical journey in the classroom with Father McGlinchey is the work that returns in the form of a posthumous publication to engage readers of his work once more. In the context of his death in 2013 Heaney's Aeneid Book VI is all the more relevant as the shades and shadows of the underworld return to us in a literary form with Heaney as the author and not Virgil, and this in itself makes the translation all the more haunting.

Ian HiCkEY

Mary Immaculate College, University of Limerick

63. Michael Parker, “'Back in the Heartland': Seamus Heaney's 'Route 110' Sequence in Human Chain", Irish Studies Review, vol. 21, no. 4, 2013, p. 381. 